Hugoye: Journal of Syriac Studies, Vol. 13.1, 9-30

(C) 2010 by Beth Mardutho: The Syriac Institute and Gorgias Press

\title{
PAPERS
}

\section{NEW EVIDENCE ON THE PHILOXENIAN VERSIONS OF THE NEW TESTAMENT AND NICENE CREED}

\section{DANIEL KING}

\section{CARDIFF UNIVERSITY}

In the era after the Council of Chalcedon, the corpus of the 'Church Fathers' became a source-book for doctrinal elaboration and the authority attributed to their works rivaled that of the scriptures themselves. ${ }^{1}$ This paradigm shift in matters of authority in intra-ecclesial disputes had begun already with Cyril of Alexandria who not only laid down in the seventh canon of the Ephesian Council of 431 that henceforth only the Creed of the 318 Fathers of Nicaea was to be permitted as the touchstone of orthodoxy, ${ }^{2}$ but he also initiated the custom of quoting from the

1 For a fuller description of the phenomenon see, for instance, P.T.R. Gray, "Through the Tunnel with Leontius of Jerusalem: The SixthCentury Transformation of Theology," in The Sixth Century, End or Beginning?, ed. P. Allen and E. Jeffreys (Brisbane: Australian Association for Byzantine Studies, 1996), 187-96.

${ }^{2}$ He wanted to 'set down dogma' by 'raising up the Fathers' (Acta Conciliorum Oecumenicorum, ed. Schwartz, I,1,4, p. 30,21-2). Cyril even engaged in the later popular activity of accusing (or defending against 
unimpeachable 'Nicene' fathers as a means of grounding his own theological position in the tradition of the 'orthodox' church. ${ }^{3}$ Hence the lengthy anthology of proof-texts from the Fathers (a florilegium) which was appended to the official Acts of the Council of Ephesus and which itself became the source and fountainhead for patristic florilegia everywhere, among all theological groupings. ${ }^{4}$

In the conversations that took place between representatives of the Imperial (Chalcedonian) Church and a group of antiChalcedonian bishops in 532 (a number of whom were Syrians by language), the focus was not on philosophical discussion or even on scriptural interpretation but rather on the patristic support for their relative positions. ${ }^{5}$ The Syrian bishops quoted texts with which they were evidently familiar in their own tongue, which is hardly surprising when we see the size of the florilegia that had by this time developed and which may have been available to them. ${ }^{6}$

accusation) texts produced by opponents of having been interpolated or adulterated, as we see from his letters to Acacius and Succensus-see R.Y. Ebied and L.R. Wickham, "Athanasius' Ad Epictetum" (Journal of Theological Studies 23 [1972]), 144-54.

${ }^{3}$ He gathers collections of citations in both the De Recta Fide ad Dominas and the Apologia contra Orientales, in both cases using citations that are also found in the Ephesine florilegium.

${ }^{4}$ The Collectio Ephesena can be found at ACO I,1,2,39-45. On the early patristic florilegia, e.g. H. Chadwick, "Florilegium," in Reallexikon fir Antike und Christentum, ed. T. Klauser (Stuttgart: Anton Hiersemann, 1969), 7:1131-60, and M. Richard, "Les Florilèges diphysites du Ve et du VI siècle," in Das Konzril von Chalkedon: Geschichte und Gegenwart I, ed. A. Grillmeier and H. Bacht (Wurzburg: Echter-Verlag, 1951), 721-43.

${ }^{5}$ A good summary in V.L. Menze, Justinian and the Making of the Syrian Orthodox Church, Oxford Early Christian Studies (Oxford: University Press, 2008), 58-67. For the texts describing the meeting, S.P. Brock, "The Conversations with the Syrian Orthodox under Justinian (532)" (Orientalia Christiana Periodica 47 [1981]), 87-121.

${ }^{6}$ A number of late antique Syriac florilegia of this type are extant. Some are extraordinarily large and varied in their contents, indicating a long textual prehistory. Perhaps the most important is BL Add. 12156, dated before 562, which includes the so-called Florilegium Edessenum, [A. Rücker, Das Syrische Florilegium Edessenum anonymum (ante 562), Sitz. der Bayerischen Ak. der Wiss. Phil-hist. Abt., Hft 5, München, 1933], among other important documents and collections (see L. Abramowski, "Zur 
In addition to the famous Apollinarian texts attributed to Athanasius and others, and a first public outing for ps-Dionysius, these included also some of the key letters of Cyril of Alexandria that had been written in the wake of the Council of Ephesus during the period when Cyril was trying to forge a reconciliation with John of Antioch. These few letters became a battle-ground later in the fifth century since their conciliatory language could be used by proChalcedonians to draw the legacy of Cyril away from the clutches of their opponents. ${ }^{7}$

Cyril's letters were foundational and identity-forming texts for members of the increasingly independent Miaphysite church in Syria. For these opponents of Chalcedon the letters affirmed that their own position was also that of the Fathers and that the dupes of Pope Leo and his Council had veered from the true path of orthodox tradition. In the debate at Constantinople in 532 the parties argued over what the Fathers had said and who was now in ownership of true patristic tradition. ${ }^{8}$

That such texts were central to anti-Chalcedonian strategy was true even long before the renewed urgency of the years of persecution under Justin and Justinian. For ever since Cyril himself sent one of his Christological treatises to bishop Rabbula of Edessa

geplanten Ausgabe von Brit.Mus.add.12156," in Texte und Textkritik: Eine Aufsat:sammlung, Texte und Untersuchungen 133, ed. J. Dummer (Berlin: Akademie-Verlag, 1987), 23-8, and R.Y. Ebied and L.R. Wickham, "Timothy Aelurus: Against Chalcedon," in After Chalcedon: Studies in Theology and Church History offered to Professor Albert van Roey for bis seventieth birthday, Orientalia Lovaniensia Analecta 18, ed. C. Laga et al. (Leuven: Peeters, 1985), 115-66). A more thorough study of the descent and influence of key groups of patristic loci in Syriac translation would be very revealing. A study on the monastic compilations has been started, H. Teule, "Les compilations monastiques syriaques," in Symposium Syriacum VII, ed. R. Lavenant (Rome: Pontificio Istituto Orientale, 1998), 249-64.

7 This was the purpose of the Florilegium Cyrillianum, which caused a furore in Constantinople when it appeared and was enough to make Severus write a full length rebuttal in his Philalethes.

8 Hence the key debates over who had accepted as orthodox individuals later shown to be heretical, whose names should be erased from (or restored to) the diptychs, etc. 
in 432, the Syriac-speaking church had been transmitting these texts and translating them. ${ }^{9}$

Philoxenus received his theological education in Edessa during the very years of the polarisation of the anti-Chalcedonian/proCyrilline legacy of Rabbula and the Antiochene/pro-Theodoran legacy of Hiba (Ibas). ${ }^{10}$ The strife came to a head around 448 when Hiba's Letter to Mari, in which the bishop accuses Cyril's anathemas of being unorthodox, became widely known. This led to Hiba's deposition following the so-called 'Robber' Council in Ephesus in 449. From this point on the two groups vied for the intellectual and political high ground, at least until the Emperor Zeno in 489 closed down the 'School of the Persians', which had become the principal base for the pro-Theodoran party loyal to Hiba, a party that was now to be labeled as 'Nestorian'. Hence while the future bishop of Mabbug was studying in Edessa as a young man he was able to experience life in both camps. ${ }^{11}$ We would expect that

9 Cyril, Ep74 (tr. in J.I. McEnerney, St. Cyril of Alexandria: Letters, Fathers of the Church 76-7 (Washington, D.C: Catholic University of America Press, 1987)) tells us that the text was sent to Rabbula on the latter's request soon after the Council. Whether the extant Syriac De Recta Fide ad Theodosium is in fact the text in question cannot be ascertained for certain (B. Aland and A. Juckel, Das Neue Testament in syrischer Überlieferung I. Die Grossen Katholischen Briefe, Arbeiten zur neutestamentlichen Textforschung, Bd 7 (Berlin: Walter de Gruyter, 1986), 94-107), but we can be sure at least that there was a corpus of Cyrilliana available before the final quarter of the fifth century, on which see further below.

${ }^{10}$ On the unrest between these parties, see R. Doran, Stewards of the Poor: The Man of God, Rabbula, and Hiba in Fifth-Century Edessa (Kalamazoo: Cistercian Publications, 2006). The contest between them was well known to later Miaphysite tradition (e.g. to Simeon of Beth-Arsham: A. de Halleux, Philoxène de Mabbog: sa vie, ses écrits, sa théologie (Leuven: Imprimerie Orientaliste, 1963), 25-6).

11 De Halleux, Philoxìne de Mabbog, 25-30. Philoxenus seems to have started out by naturally attaching himself to the 'schools' which taught exegesis from Theodore and which looked to the Antiochene tradition generally. Although he never lost some of what he learnt at this period, he was drawn ever more into the orbit of the party of Rabbula and would end up by denouncing the doctrines of his former teachers as the bitter cup of Nestorianism', as he recounts in his second letter to the monks of Beth Gaugal. 
during this time he read and digested the central patristic prooftexts being used by the Cyrilline (becoming after 451 the antiChalcedonian) party, which included the Apollinarian forgeries as well as letters and treatises of Cyril. Indeed he later reflected upon the contents of these works. ${ }^{12}$ Our expectation is confirmed when we see Philoxenus deploying texts both at the beginning of his career, in his ecclesiastical battle against Habbib (his very earliest significant piece of theological exposition), and again at the end, in the letter to the monks of Senoun, written from exile forty years later.

The first of these, the Ten Memre against Habbib, was written, according to De Halleux, between the promulgation of Zeno's Henoticon in 482 and Philoxenus' appointment as bishop of Mabbug in 484. Appended to the end of the tenth memra was a patristic florilegium in which citations from Ephrem are woven together with citations from the Fathers of the Greek church, Basil, Gregory, Athanasius, Cyril, and others. ${ }^{13}$

Now the matter of patristic florilegia in Syriac is closely tied to questions of translation. So often one would like to know whether Syriac authors are reading their Greek predecessors in Syriac translation or whether their access was mediated solely through excerpts preserved in florilegia, and if the latter, then whether such collections were formed first in Greek and then translated as

12 In his Letter to the Monks of the Orient, Philoxenus describes the events of Cyril's reconciliation with John of Antioch, which is grounded in a close reading of Cyril's letters to Acacius (Ep 40) and Succensus (Ep 45/46).

13 De Halleux, Philoxène de Mabbog, 225-38. The Memre were published by M. Brière and F. Graffin, Sancti Pbiloxeni Episcopi Mabbugensis Dissertationes Decem, in Patrologia Orientalis. The first two memre appeared in PO 15,4 [1927], the rest rather later (Memre 3-5 in PO 38 [1977]; Memre 5-8 in PO 39 [1979]; Memre 9-10 in PO 40 [1980] and the appendices, including our florilegium, in PO 41 [1982]). On the appended florilegium, F. Graffin, "Le florilège patristique de Philoxène de Mabboug," in Symposium Syriacum 1972, Orientalia Christiana Analecta 197 (Rome: Pont. Inst. Or. Stud., 1974), 267-90. On other aspects of the theology of the Memre, L. Van Rompay, "Bardaisan and Mani in Philoxenus of Mabbug's Memre against Habbib," in Syriac Polemics: Studies in Honour of Gerrit Jan Reinink, ed. W.J. Van Bekkum et al. (Leuven: Peeters, 2007), 77-90. 
collections or whether the anthologies were compiled from alreadytranslated discrete texts. Very often, clear answers to such questions are impossible. In the case of the florilegium found at the end of the Ten Memre against Habbib, a mixture of sources is apparent.

The collection in question includes citations from some of the lesser known writers of the fourth/fifth century, such as Theophilus of Alexandria and Atticus of Constantinople, whose works were unlikely ever to have been translated into Syriac, at least not as early as the 480s. These citations probably come from a florilegium in Greek closely related to the Ephesine collection found in the published Acts of the Third Ecumenical Council. ${ }^{14}$ On the other hand, there are also numerous citations from the Syriac writer Ephrem which did not of course require translation. Others must have been taken from Syriac translations of whole Greek texts. Such has already been shown to be the case for the citations from Athanasius, for in this case Philoxenus' quotations match almost verbatim their parallels in the complete Syriac versions where these have been preserved such that the latter are the only possible source for the former. ${ }^{15}$ A Syriac collector evidently took them from the Syriac version of the Athanasian corpus. This observation has allowed scholars to determine a terminus ante quem for the Syriac version of Athanasius, since the date of the florilegium is fixable as c. 484 .

What has not previously been noted, however, is that the citations from Cyril of Alexandria's letters fall into the same category. The florilegium includes texts from Cyril's two letters to Succensus (Epp 45/46), his letter to Acacius (Ep 40), and that to Valerian (Ep 50), and in all four cases the same match-up can be made between the citations in the florilegium and the full versions

14 The provenance of such loci can be followed through numerous florilegia. Philoxenus' citation from Theophilus is paralleled in Cyril's Oratio ad Dominas and Timothy Ailuros' Against Chalcedon; that from Alexander of Alexandria is found also in the Syriac Florilegium Edessenum. Doubtless many lines of reception can be drawn to indicate how these collections were used and re-used in different contexts and ultimately traced back to the collection in the Acta Ephesena.

${ }^{15}$ L. Van Rompay, "Mallpânâ dilan Suryâyâ: Ephrem in the Works of Philoxenus of Mabbog: Respect and Distance” (Hugoye 7.1 [2004]), §13. 
of these letters which are to be found in a seventh century British Library ms. ${ }^{16}$ These letters must all have been translated into Syriac before 484 at the latest and furthermore we can estimate that they, among others, must have had a pronounced influence upon the young Philoxenus. ${ }^{17}$ The Christological formulae which become central to his polemical works are Cyrilline in nature and are drawn at least in part from these key letters. The various sets of anathemas which Philoxenus drew up on different occasions are grounded upon Cyril's famous twelve anathemas, some of which he discusses in these letters and which he defended at greater length in two other treatises which may also have been translated already in the fifth century. ${ }^{18}$

Making use of evidence such as this, we can begin to build up a picture of the sorts of texts that Philoxenus, whose ability to read Greek was probably never more than rudimentary at best, might have been studying in his formative years and which influenced his early theological writings. We can at least be certain that a corpus of the anti-Nestorian writings of Cyril of Alexandria was already circulating in the middle third of the fifth century, most likely emanating from Edessa, the very place where Philoxenus received

${ }^{16}$ For the full evidence, see D. King, The Syriac Versions of the Writings of Cyril of Alexandria: A Study in Translation Technique, CSCO 626, Subsidia 123 (Leuven: Peeters, 2008), 45-59. This technique can be used to date other Syriac translations. The Apollinarian corpus, for example, must have been translated early in the sixth century at least, since citations from it are to be found in Philoxenus' Letter to the Monks of Senoun which match verbatim the fuller versions of the texts in BL Add. 12156, edited in the collection of J.P.G. Flemming and H. Lietzmann, Apollinaristische Schriften syrisch, Berlin, 1904.

${ }^{17}$ The letters to Succensus and Acacius were both in the possession of the Syrian (anti-Chalcedonian) delegation to the conversations of 532 at Constantinople (Brock, "Conversations with the Syrian Orthodox," 104). Ownership of the Cyrilline teaching was a crucial cornerstone of their position.

${ }^{18}$ Namely, the Apologia contra Orientales and Apologia contra Theodoretum. For the possible dating of the Syriac versions of these, King, Cyril of Alexandria, 356. 
his theological education and experienced the theological dialectic which shaped the path of his future career. ${ }^{19}$

Once we recognize that translations from the Greek had played a central role in the formation of Philoxenus' theology (both in terms of the patristic translations we have been discussing and also naturally the Scriptures themselves), it becomes less surprising that translation as such became a burning issue in his episcopal career and also one that was always a double-edged sword. ${ }^{20}$ It is our aim now to show that Philoxenus' reading of the Graeco-Syriac translation literature informed the translation projects that he sponsored in later years, both in matters of general import and in matters of detail. It must be stressed that Philoxenus himself was not a translator (his knowledge of the Greek language was never sufficient for this) and is by no means the only mediator of significant new turns and trends within the Graeco-Syriac translation programme. ${ }^{21}$ The influences we shall evidence below for the impact of earlier patristic translations upon the Philoxenian New Testament revision could well have been felt without Philoxenus and indeed his understanding of such processes was never profound. Nevertheless he explicitly took a great interest in these new trends, argued forcefully on their behalf and, perhaps most importantly, he drew out their theological significance and claimed them for his own doctrinal party, thereby denying them to his opponents within the Syriac church and positioning himself squarely within the tradition of the 'orthodox Fathers'.

${ }^{19}$ We cannot be sure that Edessa was the origin of the translations, but it remains the most likely place for Philoxenus to have first encountered them. See King, Cyril of Alexandria, 356. For the wider issue of Cyril's influence on the theology of Philoxenus, op.cit., 348-52.

${ }^{20}$ For Philoxenus' very ambivalent attitudes towards the translation project, see D.A. Michelson, "It is not the custom of our Syriac language...': Reconsidering the Role of Translation in the Polemics of Philoxenos of Mabbug," paper presented at Shifting Frontiers VIII: Shifting Cultural Frontiers in Late Antiquity, Indiana University, Bloomington, Ind., April 2-5, 2009, forthcoming in conference proceedings.

21 On the subject of Philoxenus' utility in the Greek language, De Halleux, Philoxène de Mabbog, 20-2, although of course his lack of real knowledge did not prevent the bishop from pontificating on the subject on many occasions. 
The best known of the revised translations made during the period of Philoxenus' episcopate is of course that of the New Testament, executed under his supervision in $507 / 8$ by the chorepiscopus Polycarp. A few years earlier, at least by the year 500, the bishop of Mabbug had ordered a similar revision to be carried out on the text of the Nicene creed, thereby posing a direct challenge to traditional Syriac theology and enforcing his own formulae on the liturgical patterns of his church..$^{22}$

De Halleux has carefully reconstructed the different stages of this revision and how the new wording adopted for key Christological terms fitted into a typology of different Syriac expressions describing the incarnation. ${ }^{23}$ The most significant and readily observable of the linguistic phenomena he describes concerns the translation of the Greek passive participles of the

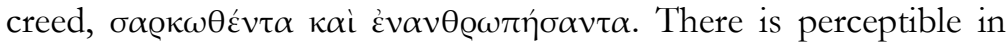
the Syriac sources a gradual shift from the 'old style' creedal formula revic ramo rive was clothed with a body and became a man) which we find, for example, in the Eastern creed of $410,{ }^{24}$ through revir (be was em-bodied and became a man) which Philoxenus tells us was current in his day, ${ }^{25}$ and then finally

22 To this extent, his actions should be seen as comparable to Peter the Fuller's addition to the Trishagion in the Antiochian liturgy. For Philoxenus' views on traditional Syriac theological language, see Van Rompay, "Mallpânâ dilan Suryâyầ" (see n. 15 above).

23 A. de Halleux, "La Philoxénienne du symbole," in Symposium Syriacum II, Orientalia Christiana Analecta 205, ed. R. Lavenant (Rome: Pont. Inst. Or. Stud., 1978), 295-315. De Halleux's discovery has been applied in other contexts, e.g. L. Van Rompay, "Proclus of Constantinople's 'Tomus ad Armenios' in the Post-Chalcedonian Tradition," in After Chalcedon: Studies in Theology and Church History offered to Professor Albert van Roey for his seventieth birthday, Orientalia Christiana Analecta 18, ed. C. Laga et al. (Leuven: Peeters, 1985), 425-49.

24 A. Vööbus, "New Sources for the Symbol in Early Syrian Christianity" (Vigiliae Christianae 26 [1972]), 295,16.

25 The term the is rejected by Philoxenus as being the 'traditional' Syriac term. It is not, however, used in the older Syriac literature nor in the Peshitta ( expression for the incarnation), but seems to have been gradually introduced in some contexts during the fifth century, for we find it in Narsai and in some of the creeds of the Eastern councils of that century. 
to the calqued terms vistro iosir (he was en-fleshed and enmanned) that we find in Philoxenus' later works, ${ }^{26}$ and which he explains and defends in the Letter to the Monks of Senoun. On finding this specialised terminology in a creed copied in a manuscript dated 500/501 in Mabbug itself, De Halleux concludes that he had here located the 'Philoxenian' version of the Creed.

De Halleux justifiably adds that Philoxenus, not himself being a good reader of Greek, was probably not the inventor of these neologisms, which was rather some 'meilleur helléniste' (p. 307) and that, even then, the terms may have been used sporadically before Philoxenus set his seal upon them by including them in the official version of the creed of the church of Mabbug. ${ }^{27}$

Bearing this in mind, and taking into account the discussion above about the importance of Greek patristic texts in Syriac in the fifth century, especially their impact upon the young Philoxenus, we should take especial note of instances of these neologisms in earlier texts. For example, iostir is far from being a complete novelty in the Philoxenian version of the Creed. It is to be found already in the Syriac versions of Cyril of Alexandria's Letter to Acacius (Ep 40) and also in the Second Letter to Succensus (Ep 46) both of which, as we saw earlier, must have been translated before 484 and with both of which Philoxenus was familiar. ${ }^{28}$ De Halleux deals briefly with these letters, but his analysis is a little superficial. ${ }^{29} \mathrm{He}$ argues simply that the apparent mixture of terminology found in these letters is typical of the period when the old usages had not yet

${ }^{26}$ There was in fact an intermediate stage in which visdiro ary dir is found, e.g. in the Letter to the Monks of Palestine (A. de Halleux, "Nouveaux textes inédits de Philoxène de Mabbog I: Lettre aux moines de Palestine; Lettre liminaire au Synodicon d'Éphèse" (Le Muséon 75 [1962]), 37,115 etc.) and in a number of translation texts.

${ }^{27}$ De Halleux, "La Philoxénienne du symbole," 307.

28 R.Y. Ebied and L.R. Wickham, A Collection of Unpublished Syriac Letters of Cyril of Alexandria, CSCO 359/360 (Leuven, 1975), 32,22/52,27. In the latter we also find the derived noun rhovionsos $(50,22)$.

${ }^{29}$ De Halleux, "La Philoxénienne du symbole," 313-4. The principal problem with this brief analysis is that he treats all the texts published by Ebied and Wickham (see previous note) as a corpus, whereas in fact the Letter on the Creed (Ep 55), to which he refers, is certainly of much later date than the others just mentioned. 
been wholly superseded by the new. This is only partially true. What we find, in fact, is that the letters which are later in date occasionally preserve earlier forms (as in the vistira rseldir of Cyril's Letter on the Creed $)^{30}$ and the ones that can now be shown to be early (Letters to Acacius and Succensus) sporadically show instances of later forms. Once these latter texts have been properly located chronologically and are read in terms of their importance to the younger Philoxenus (we recall that he quotes them in his florilegium), their lexical usage takes on a new significance in parallel with De Halleux's abovementioned suggestions about the 'meilleur helléniste' who preceded Philoxenus.

Now it could be objected at this point that some later scribe has revised the vocabulary of the early letters in line with the Philoxenian Creed. But the letters as a whole show no signs of such revision. Much vocabulary that one might expect to see changed in a scribal reworking is left untouched and, most importantly, by no means is every instance of $\sigma \alpha \varrho \kappa \omega \theta \tilde{\eta} v \alpha \iota$ rendered with iosdir. ${ }^{31}$ So in fact there is a dual usage, the older terms predominating, the newer occasionally poking their noses in and suggesting alternative futures. We find this pattern elsewhere in fifth century translations. In the Syriac version of Cyril's Quod Unus sit Christus, for example, which may come from the same period, we find side by side both the 'Philoxenian' creedal terminology and the clothing metaphor of the incarnation which Philoxenus specifically abjured. ${ }^{32}$

What I believe we are seeing in these key texts, then, is not haphazard and patchy revision post-Philoxenus, nor postPhiloxenian texts that retain some older usages, but rather some fifth century Syrian translators experimenting with the target language's capabilities in dealing with the technical vocabulary of Greek Christology, trying out different options and beginning to come to the conclusion that the traditional terms of Syriac theology

${ }^{30}$ Ebied and Wickham, Unpublished Syriac Letters, 5,15.

${ }^{31}$ In fact, in the Letter to Acacius we find both iostir and ary dir within the very same sentence (Ebied and Wickham, Unpublished Syriac Letters, 32,22).

32 For the neologisms in Quod Unus Sit Christus, BL Add. 14657, f.51va,65rb,79vb. For the expression riv a in the same text, f. 54ra, 51va,80va,87ra. 
are insufficient for the church's dogmatic task in the debate over Chalcedon.

\section{THE RELATIONSHIP}

\section{Between the Philoxenian New Testament AND EARLIER PATRISTIC TRANSLATIONS}

Let us look at the question from another angle by turning from the matter of the Creed to the better known question of the Philoxenian version/revision of the New Testament. Whether it is at all possible to reconstruct Philoxenus' revision, and if so how, has been a vexed issue for a long time and remains to some extent a divisive one, with some scholars being only too happy to find 'citations' from the Philoxenian in any deviation from the Peshitta in the sixth century literature, others being wary of any results achieved by such a method.

It was Zuntz who originally put forward the view that the Philoxenian was a 'half-way house' to the better attested Harclean revision of a century later and who first used citations in Philoxenus' own work as a way into the problem..$^{33}$ The few verses explicitly discussed by Philoxenus in his Commentary on the Johannine Prologue have proved sufficient to confirm Zuntz's view. ${ }^{34}$ But can any more be reconstructed than is possible from these scant remains? Barbara Aland has argued that many writers of the sixth century probably quoted from the Philoxenian more or less literally and that if one uses as a criterion the agreement of citations in the late writings of Philoxenus with parallels in the translation literature

33 G. Zuntz, The Ancestry of the Harklean New Testament, British Academy Supplementary Papers VII (London: British Academy, 1945).

34 S.P. Brock, "The Resolution of the Philoxenian/Harclean Problem," in New Testament Textual Criticism: Its significance for Exegesis. Essays in Honour of Bruce M. Metrger, ed. E.J. Epp and G.D. Fee (Oxford: Clarendon Press, 1981), 325-43. The Commentary on the Johannine Prologue was not yet published when Zuntz made his study. For a fuller summary and assessment of the scholarship than is possible here, King, Cyril of Alexandria, 281-92. 
of the sixth century one can be reasonably sure of reconstructing Philoxenus' version on such a basis. ${ }^{35}$

This very optimistic approach has run into some difficulty. Romeny has responded that in order to show for certain that a translator is using an existing, authoritative version rather than simply translating the Greek 'as it is', one would have to find citations inexplicable on any other grounds, i.e. one would have to find citations in the translation literature which vary significantly from their Vorlagen and indicate the use of another source such as a 'Philoxenian' version. ${ }^{36}$ For the most part this is almost impossible since the Vorlagen are not usually extant. ${ }^{37}$ In most, if not all, cases, similarities between citations in Philoxenus and citations in the translations are better explained as a result of a broad stream of tradition, what Aland herself calls a 'Philoxenian/Harclean Tradition'. ${ }^{38}$ This 'tradition' arose as translators gradually ceased their earlier practice of replacing scriptural citations with their Peshitta equivalents and started instead to make their own versions simply on the basis of the Greek before them..$^{39}$

35 B. Aland, "Die philoxenianisch-harklensische Übersetzungstradition: Ergebnisse einer Untersuchung der neutestamentlichen Zitate in der syrischen Literatur" (Le Muséon 94 [1981]), 321-83.

${ }^{36}$ B. ter Haar Romeny, "A Philoxenian-Harclean Tradition? Biblical Quotations in Syriac Translations from Greek," in Syriac Polemics. Studies in honour of Gerrit Jan Reinink, ed. W.J. Van Bekkum et al. (Leuven: Peeters, 2007), 59-76. By applying this slightly harsher criterion, Romeny throws doubt on the previously asserted existence of a Philoxenian version of the Psalter (e.g. p. 63-5).

37 This is true at least for the Severan corpus and Cyril's Homilies on Luke (save in both cases for the fragments found in the Catenae). For the texts of Cyril, Gregory etc. we are more fortunate with regard to the Vorlagen, but these are less firmly datable.

38 The expression was coined by Barbara Aland in the above mentioned article. The 'tradition' concerns only translations from the Greek; native Syriac literature tends to be much more conservative and quotes simply from the Peshitta even after revisions were available.

39 This is a practice everywhere discernible in Syriac literature and especially in the translation of Greek commentaries on the Old Testament where the clash between Peshitta and LXX was sometimes too obvious to avoid. A variety of solutions were tried (L. Van Rompay, "The Christian Syriac Tradition of Interpretation," in Hebrew Bible, Old Testament: The 
In a number of places within his essay, Romeny notes issues that are of importance for our present purpose. For instance, he urges the possible use of "comparable material from earlier periods which might show a text which is also mid-way between the Peshitta and the Harclean," and makes the obvious but vitally important point that "the work of Philoxenus' aide Polycarp stands in - rather than at the beginning of-this line [of translation tradition]." "40 Let us turn now to a few selected examples of 'comparable material from earlier periods.'

The general tendency of translators to move beyond the insertion of the Peshitta and to produce renderings that are closer to the Harclean is especially transparent in the case of certain key terms. For instance, the Old Syriac gospels, in line with traditional

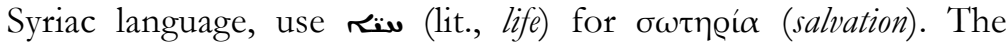
Peshitta tentatively begins the process of replacing this with roing and cognate terms (e.g. at Lk 1.69,77,2.11, while all other instances are left as in the Old Syriac) and the Harclean finishes the process by changing all such terms without exception. In translations datable to the first half of the sixth century, we can see a stage in between the Peshitta and the Harclean where more instances have undergone the change in question-e.g. at Lk 3.6 where the Peshitta's wiv has been replaced by ming (Hcl: mb. r ring. ${ }^{41}$

In the two translation texts that show this particular reading, Cyril of Alexandria's Scholia on the Incarnation and Explanation of the Twelve Chapters, which may well have been translated by the same individual, almost certainly in the sixth century and probably in

History of its Interpretation, Vol. 1, Pt. 1, ed. M. Sæbø (Göttingen: Vandenhoeck \& Ruprecht, 1996), 615). Moses of Aggel's preface to his translation of Cyril of Alexandria's Glaphyra deals expressly with this issue in the context of exegesis. The changing practice is quite transparent in the Cyril translations: King, Cyril of Alexandria, 277-314.

${ }^{40}$ Romeny, “A Philoxenian-Harclean Tradition?," 68,75.

${ }^{41}$ King, Cyril of Alexandria, 426. The gradual replacement of Riw with roing is typical of the shift away from traditional Syriac formulae towards a more 'faithful' reflection of Greek terminology. To this extent, roing is a loan translation. 
the earlier part thereof, ${ }^{42}$ the New Testament citations are sometimes closely allied to the Peshitta and are sometimes identical with the Harclean. When the latter is the case we can call the resulting version part of the 'Philoxenian/Harclean Tradition', although we cannot be sure whether these words stood in the Philoxenian per se.

In other cases, the revisions in the Harclean were less theologically motivated and had more to do with the holy grail of consistency. Thus the Greek тótos is rendered in the Old Syriac almost randomly by either Rhoas (Mt 26.52 etc.) or by Ridir (Mt 14.13 etc.), although ridir prevails on the whole. The Peshitta sometimes replaces ridir with rhan (Mt 27.33) but for the most part leaves the Old Syriac in tact. The Harclean uses rhoox throughout as a matter of principle, replacing all the Peshitta's instances of ridir. In the case of Jn 14.2 there was a revision of ridir to rhan not only in the Harclean but in all sixth century translations and in the citation in Philoxenus' Commentary on the Johannine Prologue. It seems very likely that the Philoxenian had made this particular revision almost, if not entirely, throughout the New Testament already before Thomas of Harkel finished the job. ${ }^{43}$

At 1 Cor 1.23, the same pattern is quite evident both in the

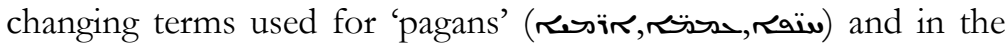

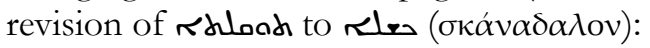

42 The Explanatio can be dated before 521 on the basis that Philoxenus quotes the Cyrilline anathemas according to the version found in the revised form of the Explanatio in a letter of that date (op. cit., 339).

43 Very often it would appear that the changes in translation practice over the fifth to seventh centuries were characterized not so much by the introduction of wholly new techniques (though there are undoubtedly some of these) but by the more complete and consistent application of existing techniques. Hence the simple appearance of more 'literal' techniques is not necessarily a guarantee of a later date-rather one must look to the consistency of usage of that particular characteristic. 
1 Cor 1.23

Peshitta

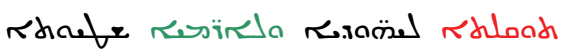

Paul of Callinicum, Sev. Hom.

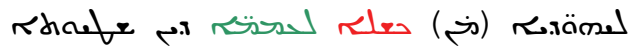

Paul of Callinicum, Sev. Philalethes

Cyril, Scholia

Harclean

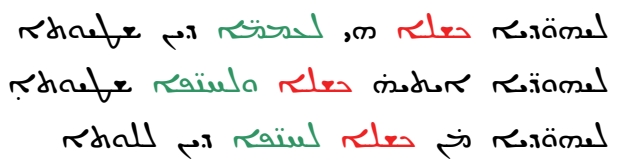

Now to this pattern we can add $\alpha$ citation from Philoxenus'

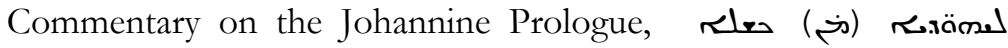

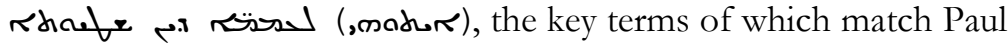
of Callinicum very closely. The Scholia citation has moved one step further toward the Harclean. We can be reasonably sure in this case that the Philoxenian must have looked very like what Philoxenus has in his Commentary. We cannot conclude that Paul of Callinicum always or consistently follows the Philoxenian, but we can see the development of the 'Philoxenian/Harclean' tradition as it moves through these various texts in the sixth-century (Paul of Callinicum translated the Severan corpus in the 520s; Cyril's Scholia is probably from the same period) ${ }^{44}$ which tend to share principal characteristics, even where they do not follow each other verbatim. This 'Philoxenian/Harclean Tradition' is not always to be found literally in all the translations - hence the revision of 7 id to ara evidenced in the Commentary on the Johannine Prologue and in the Harclean is matched in some of the sixth century translation literature but not in all. 45

Now to return to those key letters of Cyril of Alexandria, for which the terminus ante quem is 484. In line with fifth century translations in general, these texts follow the Peshitta for their citations rather than creating their own new versions. However, just as we saw a few scattered examples of the revised creedal language cropping up in these early texts, so also we see signs of the 'Philoxenian/Harclean Tradition' of New Testament revision.

${ }^{44}$ King, Cyril of Alexandria, 356.

${ }^{45}$ Mt 1.23 (for details, ibid. 398). 
Thus, for instance, the replacement of riss with for for $\pi \rho \circ \beta \alpha \tau \omega \nu$ (Mt 7.15) which is found in the Harclean and which is prefigured in three translations of clear sixth century provenance can be found earlier in a citation in Cyril's First Letter to Succensus (Ep 45). The same is true of the revision of , m حis to for

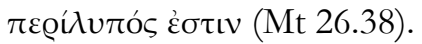

Sometimes these 'early' cases of minor revision can also be corroborated by a citation from Philoxenus' Commentary on the Johannine Prologue, e.g. at Rom 1.25:

Peshitta 46
Cyril, Ep 50
Philoxenus, Jn. Comm.
Cyril, Scholia
Harclean

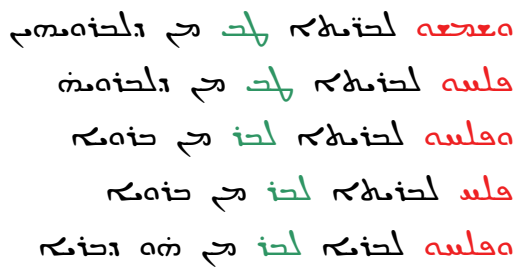

Here, Cyril's Ep 50 already prefigures a revision made by Philoxenus which was accepted in the sixth century translation literature (here represented by Cyril, Scholia) and in the Harclean. The most important of all examples of this sort, moreover, concerns the version of Hebrews 10.5. This was one of the verses which Philoxenus explicitly discusses when talking about his New Testament revision. The Peshitta read 'a body you have clothed me with', a typical piece of Syriac symbolic theology which Philoxenus wanted to do away with. On the basis of 'better' Greek texts he made his new version read, 'a body you have prepared for me'. When we turn again to Cyril's Letter to Valerian (Ep 50), we find this very 'revised' reading in a text translated long before the official promulgation of the Philoxenian New Testament itself:

46 The Peshitta of Rom 1.25 is quoted verbatim by the fifth century version of Cyril's De Recta Fide and by Sergius of Resh'aina early in the sixth century. 
Peshitta

Cyril, Ep 50

Philoxenian $^{47}$

Harclean

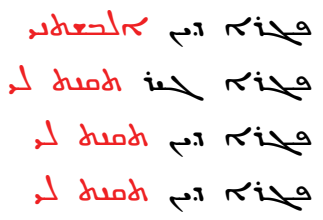

Once again we have to grapple with the possibility that a scribe has reworked the text at a later date. As argued earlier, however, there are no other signs of such reworking in these texts where we might expect to find them and the unevennesses of translation technique that they show are typical of their style in general. There is no clear evidence of revision and no need to postulate one in the presence of a better explanation.

It seems much more likely that these fifth century translators were already thinking along the same lines as Philoxenus would be a generation later, trying to translate the Greek 'as it is'. This finding is, after all, quite unsurprising. We know that Philoxenus neither read Greek himself nor was he the originator of the new approaches to translation technique that are associated with his name. We know furthermore that he was exposed to the fifth century patristic translation literature circulating among the schools in Edessa during his formative years. He cited a number of such texts in the florilegium that he wielded in his Memre against Habbib, written before he was elevated to his see in 484 .

We have now found in these letters haphazard and occasional examples both of Scriptural revisions, such as this one at Hebrews 10.5, and of the creedal revisions which Philoxenus ordered to be incorporated into the Syrian church's official liturgy around the year 500. It does not seem too far fetched to suggest that the idea of making a thorough and complete revision of both New Testament and Creed developed within the plans of Philoxenus as a result of his having read, digested, and been influenced by these early translations that we have been looking at.

The fifth century translators of Cyril were pioneer theological interpreters in their own right. Their experiments in translation

47 The Philoxenian version of Heb 10.5, as well as being discussed as a crux in the Commentary on the Johannine Prologue, is found in Philoxenus' later works (Letter to the Monks of Senoun) and in Paul of Callinicum's translations of Severus. 
shaped Philoxenus' reading and theology, and thus through his redeployment of their methods, they had a profound influence upon Syriac Miaphysite language.

If, therefore, we wish to seek antecedents for the increasing Hellenisation and literalism in Syriac translations, ${ }^{48}$ and indeed in native literature too, in the sixth and seventh centuries, we should not look so much to other Bible translation traditions in antiquity generally, but rather to patristic translations in the Syriac church in particular, and to the theological concerns which underlay their reception in the West Syrian church after Chalcedon.

The issue of precision in translation may have arisen initially within the context of scriptural citations embedded in these patristic translations, perhaps at first when Theodore of Mopsuestia's Old Testament commentaries were being translated at Edessa in the period before the schism. ${ }^{49}$ From here the problem began to assert itself in all sorts of other contexts. Although in the Patristic translations of the mid fifth century (Cyril and Athanasius above all) the Peshitta still reigns supreme, we can nonetheless watch the translators struggling to find alternative methods, especially when these citations began to involve and to extend to the terminology of doctrinal formulations such as appeared in the creeds and the Miaphysite slogans.

It is in these contexts, in the vocabulary of doctrinal formulation and the wording of the creeds, as these are expounded and elaborated in the translation literature, that we begin to see the first steps being taken towards the literalistic, 'mirror' style of translation which was fully and consistently adopted over the

48 As outlined in a number of key articles by Sebastian Brock, esp. "Towards a History of Syriac translation technique," in III Symposium Syriacum, ed. R. Lavenant (Rome: Pont. Inst. Or. Stud., 1983), 1-14; “The Syriac background to Hunayn's translation techniques" (Aram 3 [1991]), 139-62; "Changing Fashions in Syriac Translation Technique: The Background to Syriac Translations under the Abbasids" (Journal of the Canadian Society for Syriac Studies 4 [2004]), 3-14.

${ }^{49}$ For a summary of the works of Theodore in Syriac together with discussion of their dating, see L. Van Rompay, "Quelques remarques sur la tradition syriaque de l'oeuvre exégétique de Théodore de Mopsueste," in IV Symposium Syriacum, ed. H.J.W. Drijvers et al. (Rome: Pont. Inst. Or. Stud., 1987), 33-43. 
course of the sixth-seventh century for use in all genres of translation. Philoxenus, as a leader of the Miaphysite movement, threw his weight behind this cultural and theological shift. The inspiration for his doing so was the momentum already begun by those earlier patristic translations which had such a marked influenced upon his own education.

\section{BIBLIOGRAPHY}

Abramowski, L. "zur geplanten Ausgabe von Brit.Mus.add.12156." In Texte und Textkritik: Eine Aufsatzsammlung, Texte und Untersuchungen 133, ed. J. Dummer. Berlin: Akademie-Verlag, 1987: 23-8.

Aland, B. "Die philoxenianisch-harklensische Übersetzungstradition: Ergebnisse einer Untersuchung der neutestamentlichen Zitate in der syrischen Literatur." Le Muséon 94 (1981): 321-83.

Aland, B. and A. Juckel. Das Neue Testament in syrischer Überlieferung I. Die Grossen Katholischen Briefe. Arbeiten zur neutestamentlichen Textforschung, Bd 7. Berlin: Walter de Gruyter, 1986.

Brock, S. P. "The Conversations with the Syrian Orthodox under Justinian (532)." Orientalia Cbristiana Periodica 47 (1981): 87-121. Reprinted, Studies in Syriac Christianity XIII. . "The Resolution of the Philoxenian/Harclean Problem." In New Testament Textual Criticism: Its significance for Exegesis. Essays in Honour of Bruce M. Metzger, ed. E.J. Epp and G.D. Fee. Oxford: Clarendon Press, 1981: 325-43.

. "Towards a History of Syriac translation technique." In III Symposium Syriacum, Goslar 7-11 September 1980, ed. R. Lavenant. Rome: Pont. Inst. Or. Stud., 1983: 1-14.

. "The Syriac background to Hunayn's translation techniques." Aram 3 (1991): 139-62.

- "Changing Fashions in Syriac Translation Technique: The Background to Syriac Translations under the Abbasids." Journal of the Canadian Society for Syriac Studies 4 (2004): 3-14.

Chadwick, H. "Florilegium." In Reallexikon für Antike und Christentum, ed. T. Klauser. Stuttgart: Anton Hiersemann, 1969: 7:1131-60.

De Halleux, A. "Nouveaux textes inédits de Philoxène de Mabbog I: Lettre aux moines de Palestine; Lettre liminaire au Synodicon d'Éphèse." Le Muséon 75 (1962): 31-62. 
De Halleux, A. Philoxène de Mabbog: sa vie, ses écrits, sa théologie. Leuven: Imprimerie Orientaliste, 1963.

. "La Philoxénienne du symbole." In Symposium Syriacum II, Orientalia Christiana Analecta 205, ed. R. Lavenant. Rome: Pont. Inst. Or. Stud., 1978: 295-315.

Doran, R. Stewards of the Poor: The Man of God, Rabbula, and Hiba in FifthCentury Edessa. Kalamazoo: Cistercian Publications, 2006.

Ebied, R.Y. and L.R. Wickham. "Athanasius' Ad Epictetum.” Journal of Theological Studies 23 (1972): 144-54.

- A Collection of Unpublished Syriac Letters of Cyril of Alexandria. CSCO 359/360. Leuven, 1975.

. "Timothy Aelurus: Against Chalcedon." In After Chalcedon:

Studies in Theology and Church History offered to Professor Albert van

Roey for his seventieth birthday, Orientalia Lovaniensia Analecta 18, ed. C. Laga et al. Leuven: Peeters, 1985: 115-66.

Flemming, J.P.G. and H. Lietzmann. Apollinaristische Schriften syrisch. Berlin, 1904.

Graffin, F. "Le florilège patristique de Philoxène de Mabboug." In Symposium Syriacum 1972, Orientalia Christiana Analecta 197. Rome: Pont. Inst. Or. Stud., 1974: 267-90.

Gray, P.T.R. "Through the Tunnel with Leontius of Jerusalem: The SixthCentury Transformation of Theology." In The Sixth Century, End or Beginning?, ed. P. Allen and E. Jeffreys. Brisbane: Australian Association for Byzantine Studies, 1996: 187-96.

King, D. The Syriac Versions of the Writings of Cyril of Alexandria: A Study in Translation Technique. CSCO 626 (Subsidia 123). Leuven: Peeters, 2008.

McEnerney, J.I. St. Cyril of Alexandria : Letters. Fathers of the Church 7677. Washington, D.C: Catholic University of America Press, 1987.

Menze, V.L. Justinian and the Making of the Syrian Orthodox Church. Oxford Early Christian Studies. Oxford: University Press, 2008.

Michelson, D.A. "It is not the custom of our Syriac language. Reconsidering the role of Translation in the Polemics of Philoxenos of Mabbug." In proceedings of Shifting Frontiers VIII (April 2009), Forthcoming.

Richard, M. "Les Florilèges diphysites du Ve et du VIe siècle." In Das Konzil von Chalkedon : Geschichte und Gegenwart I, ed. A. Grillmeier and H. Bacht. Wurzburg: Echter-Verlag, 1951: 721-43. 
Romeny, B. t. H. "A Philoxenian-Harclean Tradition? Biblical Quotations in Syriac Translations from Greek." In Syriac Polemics. Studies in honour of Gerrit Jan Reinink, ed. W.J. Van Bekkum et al. Leuven: Peeters, 2007: 59-76.

Rücker, A. Das Syrische Florilegium Edessenum anonymum (ante 562). Sitz. der Bayerischen Ak. der Wiss. Phil-hist. Abt., Hft 5. München, 1933.

Teule, H. "Les compilations monastiques syriaques." In Symposium Syriacum VII, ed. R. Lavenant. Rome: Pont. Inst. Or. Stud., 1998: 249-64.

Van Rompay, L. "Proclus of Constantinople's 'Tomus ad Armenios' in the Post-Chalcedonian Tradition." In After Chalcedon: Studies in Theology and Church History offered to Professor Albert van Roey for his seventieth birthday, Orientalia Christiana Analecta 18, ed. C. Laga et al. Leuven: Peeters, 1985: 425-49.

. "The Christian Syriac Tradition of Interpretation." In Hebrew Bible, Old Testament: The History of its Interpretation, Vol.1, Pt.1, ed. M. Sæbø. Göttingen: Vandenhoeck \& Ruprecht, 1996: 612-41. . "Mallpânâ dilan Suryâyâ: Ephrem in the Works of Philoxenus of Mabbog: Respect and Distance." Hugoye 7.1 (2004). . "Bardaisan and Mani in Philoxenus of Mabbug's Memre against Habbib." In Syriac Polemics: Studies in Honour of Gerrit Jan Reinink, ed. W.J. Van Bekkum et al. Leuven: Peeters, 2007: 77-90.

Vööbus, A. "New Sources for the Symbol in Early Syrian Christianity." Vigiliae Christianae 26 (1972): 291-96.

Zuntz, G. The Ancestry of the Harklean New Testament. British Academy Supplementary Papers VII. London: British Academy, 1945. 